Pengembangan Rekayasa dan Teknologi, Vol 16, No. 1, Juni 2020, pp 34-44

p-ISSN: $1410-9840$ \& e-ISSN: 2580-8850

http://journals.usm.ac.id/index.php/jprt/index

\title{
Aplikasi Identifikasi Jenis Buah Kurma Dengan Metode GLCM Berbasis Android
}

\author{
Mochamad Fandi ${ }^{1)}$, Oky Dwi Nurhayati ${ }^{2}$, Rizal Isnanto ${ }^{2)}$ \\ 1,2,3 Departemen Teknik Komputer, Fakultas Teknik, Universitas Diponegoro \\ Jl. Prof. Soedarto, SH, Kampus Undip Tembalang, Semarang, Indonesia 50275 \\ mfandi@student.ce.undip.ac.id ${ }^{1}$,
}

\begin{abstract}
The dates are one of the most popular fruits in Indonesia. There are many types of dates sold on the market, therefore consumers have difficulty recognizing each type of date. This is often used by sellers of dates to cheat by mixing Ajwa dates with other types of dates. The goal of this research is to create a mobile application that can identify the types of Ajwa dates, Sukari dates, and Deglet Nour dates with image processing. The application is built using Android Studio and OpenCV as a library for image processing. The stages of the image processing process consist of pre-processing of grayscale image, thresholding segmentation, and second-order statistical feature extraction using the GLCM method. The results of this study found a success rate of $83.33 \%$ using 90 training data images and 30 test data images.
\end{abstract}

Keywords: Image Processing, Thresholding, GLCM, Android, OpenCV

\begin{abstract}
Abstrak
Buah kurma merupakan salah satu buah yang sangat populer di Indonesia. Ada banyak sekali jenis kurma yang dijual di pasaran, oleh karena itu konsumen mengalami kesulitan dalam mengenali tiap jenis kurma. Hal tersebut sering dimanfaatkan oleh penjual kurma untuk melakukan kecurangan dengan mencampurkan kurma Ajwa dengan kurma jenis lain. Tujuan dari penelitian ini adalah untuk menghasilkan aplikasi bergerak yang dapat mengidentifikasi jenis kurma Ajwa, kurma Sukari, dan kurma Deglet Nour. Aplikasi dibangun menggunakan Android Studio dan OpenCV sebagai library untuk proses pengolahan citra. Tahapan proses pengolahan citra terdiri atas pra pengolahan citra aras kebuan, metode segmentasi pengambangan, dan ekstraksi ciri statistik orde kedua dengan metode GLCM. Hasil dari penelitian ini didapatkan tingkat keberhasilan sebesar 83,33\% yang menggunakan 90 citra data latih dan 30 citra data uji.
\end{abstract}

Kata Kunci: Pengolahan Citra, Pengambangan, GLCM, Android, OpenCV.

\section{PENDAhuluan}

Penjualan kurma di Indonesia selalu mengalami peningkatan pada saat menjelang Bulan Ramadhan tiap tahunnya. Berdasarkan data dari BPS, impor kuma ke Indonesia terus meningkat dalam lima tahun terakhir. Jenis kurma yang sering dijual di Indonesia yaitu kurma Ajwa, kurma Sukari, kurma Deglet Nour, dan lain-lain ${ }^{[1]}$.

Jenis kurma yang sangat diminati yaitu jenis kurma Ajwa karena di dalam Hadits Nabi Muhammad Subhanahu wata'ala Bersabda: "Barangsiapa mengkonsumsi tujuh butir kurma Ajwa pada pagi hari, maka pada hari itu ia tidak akan terkena racun maupun sihir". Hal tersebut menyebabkan harga Kurma Ajwa menjadi mahal ${ }^{[2]}$.

Pengetahuan pembeli dalam membedakan jenis kurma masih kurang. Meskipun sudah banyak informasi mengenai ciri-ciri dari tiap jenis kurma, akan tetapi pengujian secara kasat mata sering terjadi kesalahan karena terbatasnya penglihatan manusia dan tingkat subjektivitas dari penguji yang tinggi.

Oleh karena itu, diperlukan sebuah aplikasi bergerak yang diharapkan dapat melakukan pengujian jenis buah kurma secara langsung. Untuk mengatasi permasalahan yang ada maka dibuatlah suatu aplikasi yang berguna untuk proses identifikasi citra kurma Ajwa, kurma Sukari, dan kurma Deglet Nour menggunakan metode segmentasi pengambangan dengan algoritma Binarisasi Otsu dan ekstraksi ciri orde kedua dengan Gray Level Co-Occurrence Matrix (GLCM).

Tujuan dari penelitian ini adalah untuk menghasilkan suatu aplikasi berbasis Android yang dapat digunakan untuk mengidentifikasi jenis buah kurma dengan menggunakan metode segmentasi pengambangan dengan algoritma Binarisasi Otsu dan metode ekstraksi ciri Gray Level Co-Occurrence Matrix (GLCM). 
Pengembangan Rekayasa dan Teknologi, Vol 16, No. 1, Juni 2020, pp 34-44

p-ISSN: $1410-9840$ \& e-ISSN: 2580-8850

http://journals.usm.ac.id/index.php/jprt/index

Untuk menghindari pembahasan yang meluas maka dalam Tugas Akhir ini ditetapkan batasanbatasan masalah dengan hal-hal sebagai berikut.

1. Proses pengolahan citra buah kurma menggunakan metode segmentasi pengambangan dengan algoritma inarisasi Otsu dan metode ekstraksi ciri Gray Level Co-Occurrence Matrix (GLCM).

2. Ciri orde kedua GLCM yang digunakan adalah korelasi, entropi, energi, kontras, dan homogenitas.

3. Pengujian dilakukan pada 3 jenis kurma yaitu kurma Ajwa, Kurma Deglet Nour, dan Kurma Sukari.

4. Aplikasi berjalan di ponsel cerdas dengan sistem operasi Android 6.

5. Aplikasi dibangun menggunakan Android Studio dengan pustaka OpenCV.

6. Pengambilan citra menggunakan ponsel cerdas Xiaomi Redmi Note 5 dengan resolusi kamera 12 megapiksel.

\section{KAJIAN PUSTAKA}

\section{a. Penelitian Terdahulu}

Penelitian ini dilakukan tidak terlepas dari hasil penelitian-penelitian terdahulu yang pernah dilakukan sebagai bahan perbandingan dan kajian. Adapun hasilhasil penelitian yang dijadikan perbandingan tidak terlepas dari topik penelitian yaitu mengenai identifikasi jenis buah kurma.

Berdasarkan hasil penelitian mengenai pengolahan citra terhadap buah kurma oleh Khriji, penelitian mengenai pengukuran non-destruktif dari total soluble solid (TSS) dari kurma menggunakan pencitraan near infrared (NIR). Penelitian ini menggunakan metode segmentasi yaitu pengambangan dengan algoritma Binarisasi Otsu untuk memisahkan objek kurma dengan latar belakang citra. Proses segmentasi dimulai dengan mengubah citra asli menjadi citra aras keabuan yang selanjutnya diproses menggunakan algoritma Binarisasi Otsu untuk mendapat masking objek dan hasilnya dengan menggabungkan masking dengan citra asli. Proses segmentasi ini juga disertai dengan proses morfologi closing untuk menghilangkan lubang-lubang yang ada di objek ${ }^{[3]}$.

Kemudian penelitian kedua dilakukan oleh Victra Sonata, yaitu klasifikasi jenis buah kurma menggunakan teknik pengolahan citra digital dengan metode jaringan syaraf tiruan. Proses identifikasi citra terdiri dari proses pelatihan data dan proses pengujian. Pada proses pelatihan dilakukan proses segmentasi resize dan cropping citra. Kemudian citra akan diekstraksi ciri berdasarkan warna RGB. Hasil dari ekstraksi tersebut disimpan dalam basis-data. Sedangkan proses pengujian, hasil ekstraksi ciri warna data citra uji tidak disimpan tetapi langsung digunakan untuk proses klasifikasi menggunakan jaringan syaraf tiruan perambatan balik. Hasil dari proses ini berupa informasi apakah jenis kurma tersebut. Hasilnya menunjukan bahwa akurasi keberhasilan tertinggi dengan rata-rata $72 \%$ dari 100 data uji kurma ${ }^{[4]}$.

Penelitian ketiga dilakukan oleh Ibrahim, dkk yaitu klasifikasi jenis kurma menggunakan ekstraksi ciri warna RGB dan ukuran. Langkah pertama yang dilakukan yaitu pengambilan citra menggunakan kamera untuk data uji dan latih. Proses selanjutnya hasil dari akuisisi citra dipecah menjadi 3 kanal warna yaitu merah, hijau, dan biru, selanjutnya tiap kanal dikonversi menjadi citra aras keabuan. Kemudian citra tersebut dilakukan proses segmentasi pengambangan yang menggunakan algoritma Binarisasi Otsu untuk mendapatkan masking dari objek. Proses selanjutnya adalah ekstraksi ciri berdasarkan warna RGB dan ukuran. Hasil yang diperoleh bahwa sistem hanya dapat identifikasi jenis kurma yang matang (warna kuning, merah muda, dan merah tua) ${ }^{[5]}$.

\section{b. Kurma}

Buah Kurma merupakan buah yang banyak ditemui di Timur Tengah yang memiliki kandungan nutrisi yang baik untuk tubuh manusia. Kurma mengandung makronutrien seperti karbohidrat, lemak, protein, dan serat. Karbohidrat pada kurma terdiri dari gula sederhana seperti fruktosa, glukosa, dan sukrosa. Gula sederhana ini merupakan sumber energi yang tinggi dan mudah diserap tubuh ${ }^{[6]}$.

Kurma yang sering dijual di Indonesia ada beberapa jenis, di antaranya kurma Ajwa, kurma Sukari, dan kurma Deglet Nour. Berikut ini merupakan ciri-ciri dari ketiga kurma tersebut.

\section{Kurma Ajwa}

Kurma Ajwa memiliki warna yang hitam pekat dan ada beberapa yang mendekati warna merah. Kurma Ajwa juga memiliki tekstur yang unik seperti guratan di seluruh permukaan kurma. Ukuran dari kurma Ajwa cenderung lebih kecil dibandingkan dengan jenis kurma yang lain. Contoh gambar kurma Ajwa dapat dilihat pada Gambar 2.1 ${ }^{[7]}$.

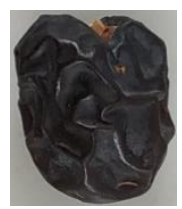

Gambar 2.1 Kurma Ajwa

\section{Kurma Sukari}

Kurma Sukari memiliki warna cokelat terang dan pada bagian ujungnya berwarna kuning ranum. Kurma Sukari memiliki tekstur renyah pada permukaan kulit 
Pengembangan Rekayasa dan Teknologi, Vol 16, No. 1, Juni 2020, pp 34-44

p-ISSN: $1410-9840$ \& e-ISSN: $2580-8850$

http://journals.usm.ac.id/index.php/jprt/index

daging kurma. Ukuran dari kurma Sukari relatif lebih besar dibandingkan dengan kurma Ajwa. Contoh gambar kurma Sukari dapat dilihat pada Gambar 2.2 ${ }^{[8]}$.

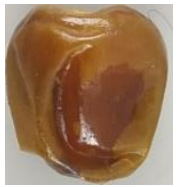

Gambar 2.2 Kurma Sukari

3. Kurma Deglet Nour

Kurma Deglet Nour memiliki warna coklat pekat. Tesktur dari kurma ini cenderung lembek dibandingkan dengan kurma Ajwa dan Sukari. Kurma ini berbentuk lonjong dan ukurannya lebih besar dibandingkan kurma Ajwa dan Sukari. Contoh gambar kurma Sukari dapat dilihat pada Gambar 2.3.

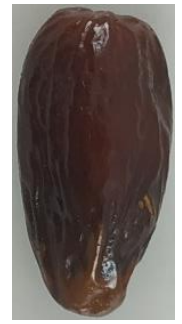

Gambar 2.3 Kurma Deglet Nour

\section{c. Pengolahan Citra}

Salah satu tujan pengolahan citra adalah mengolah suatu citra menggunakan komputer menjadi citra yang kualitasnya lebih baik. Pengolahan Citra bertujuan memperbaiki kualitas citra agar mudah diinterpretasi oleh manusia atau mesin ${ }^{[9]}$.

Citra adalah piksel-piksel yang tersusun dalam larik dua dimensi. Indeks baris dan kolom $(x, y)$ dari sebuah piksel dinyatakan dalam bilangan bulat. Piksel $(0,0)$ terletak pada sudut kiri atas pada citra, indeks $x$ bergerak ke kanan dan indeks $y$ bergerak ke bawah. Terdapat langkah-langkah dalam pengolahan citra. Gambar 2.4 merupakan tahapan pengolahan citra $^{[10]}$.

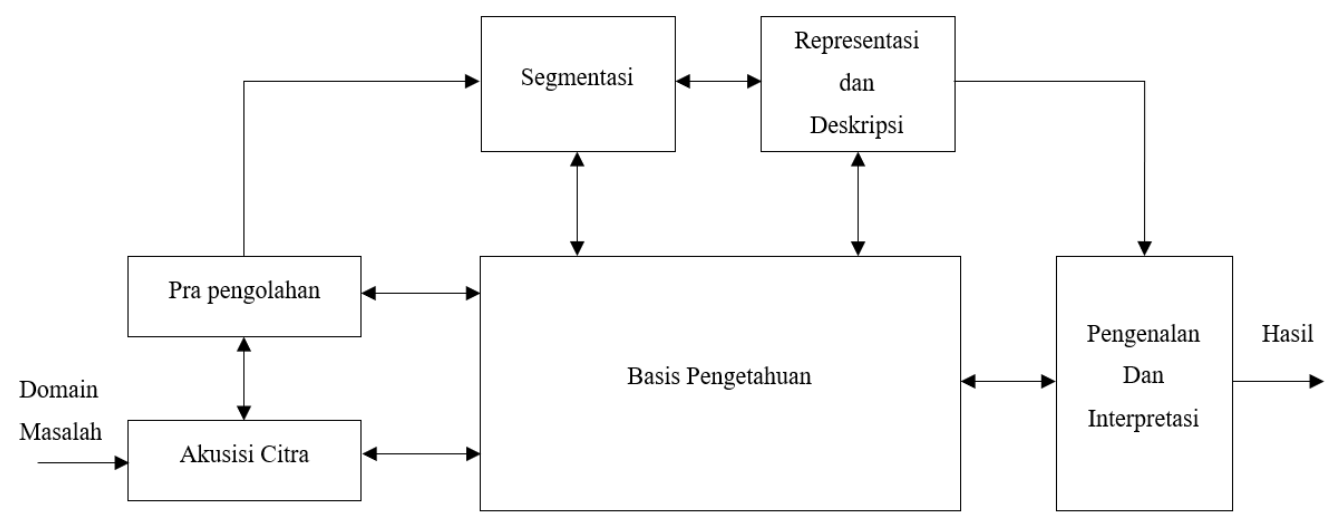

Gambar 2.4 Tahap-tahap pengolahan citra digital

\section{d. Histogram}

Informasi penting mengenai isi citra digital dapat diketahui dengan membuat histogram citra. Histogram citra adalah grafik yang menggabarkan penyebaran kuantitatif nilai derajat keabuan piksel di dalam (atau bagian tertentu) citra.

Misalkan citra digital memiliki L derajat keabuan, yaitu dari nilai 0 sampai $\mathrm{L}-1$ (misalnya pada citra dengan kuantisasi derajat keabuan 8-bit, nilai derajat keabuan dari 0 sampai 255). Gambar 2.5 menunjukan contoh histogram citra $^{[11]}$.

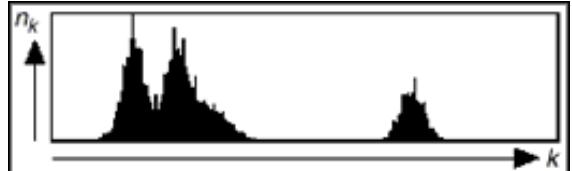

Gambar 2.5 Histogram citra

\section{e.Segmentasi Pengambangan Binarisasi Otsu}

Metode Otsu ini didasarkan pada histogramnya. Dasar dari metode Otsu adalah perbedaan intensitas dari piksel-piksel yang dipisahkan dalam kelas-kelas tertentu. Sebuah pengambangan yang mampu memisahkan kelas-kelas sehingga piksel-piksel antar kelas memiliki nilai intensitas yang berbeda, maka 
Pengembangan Rekayasa dan Teknologi, Vol 16, No. 1, Juni 2020, pp 34-44

p-ISSN: $1410-9840$ \& e-ISSN: $2580-8850$

http://journals.usm.ac.id/index.php/jprt/index

pengambangan tersebut dikatakan sudah optimal. Algoritma Binary Inv digunakan untuk mengubah piksel keabuan yang mendekati hitam menjadi putih dan piksel keabuan yang mendekati putih menjadi hitam. biner yaitu warna hitam dan putih. Sedangkan algoritma Binary digunakan untuk mengubah nilai derajat keabuan yang mendekati hitam akan menjadi hitam dan nilai derajat keabuan yang mendekati putih menjadi putih ${ }^{[12]}$.

\section{f. Metode Morfologi Closing}

Morfologi closing merupakan sebuah metode morfologi yang terdiri dari dua operasi yaitu operasi dilasi dan operasi erosi. Pada proses morfologi closing dilakukan operasi dilasi terlebih dahulu yang kemudian diikuti dengan operasi erosi. Operasi dilasi adalah operasi yang mempunyai efek memperbesar luas permukaan suatu area atau objek. Sedangkan operasi erosi merupakan operasi yang mempunyai efek memperkecil luas permukaan suatu area atau objek. Area atau objek yang dimaksud adalah area yang memiliki intensitas warna putih. Sehingga morfologi closing berguna untuk menghaluskan kontur dan menghilangkan lubang kecil di dalam area atau objek ${ }^{[10]}$.

\section{g. Metode Ekstraksi Ciri Orde Kedua GLCM}

Gray Level Cou-Occurrence Matrix (GLCM) merupakan metode untuk ektraksi ciri orde kedua yang menghitung probabilitas hubungan ketetanggaan antara dua piksel pada jarak dan orientasi sudut tertentu. Metode ini bekerja dengan membentuk sebuah matriks kookurensi dari data citra, selanjutnya menghitung fitur dari GLCM yang digunakan sebagai nilai ciri dari citra. Matriks kookurensi adalah suatu matriks yang menggambarkan frekuensi munculnya pasangan dua piksel dengan intensitas tertentu dalam jarak $(d)$ dan orientasi sudut $(\theta)$ tertentu dalam citra $^{[13]}$.

Setelah mendapatkan nilai dari matriks kookurensi yang sudah dinormalisasi, dapat dihitung ciri statistik orde kedua yang merepresentasikan citra yang diamati. Berikut adalah jenis ciri tekstural yang dapat diekstraksi dari matriks kookurensi menurut Haralick $^{[14]}$.

\section{Energi}

Energi adalah fitur yang dapat digunakan dalam analisis tekstur untuk mengukur konsentrasi pasangan intensitas pada matriks kookurensi yang didefinisikan sebagai berikut:

$$
\text { Energi }=\sum_{i} \sum_{j} p^{2}(i, j)
$$

Dengan $p(i, j)$ menyatakan nilai pada baris i dan kolom j pada matriks kookurensi.

\section{Kontras}

Kontras menunjukkan ukuran penyebaran (momen inersia) elemen-elemen matriks citra. Jika letaknya jauh dari diagonal utama, nilai kekontrasan besar. Secara visual, nilai kekontrasan adalah ukuran variasi antar derajat keabuan suatu daerah citra.

$$
\begin{gathered}
\text { Kontras }=\sum_{k} k^{2}\left[\sum_{i} \sum_{j} p(i, j)\right], k \\
=|i-j|
\end{gathered}
$$

Dengan $p(i, j)$ menyatakan nilai pada baris i dan kolom j pada matriks kookurensi.

\section{Korelasi}

Korelasi menunjukkan ukuran ketergantungan linear derajat keabuan citra sehingga dapat memberikan petunjuk adanya struktur linear dalam citra.

$$
\text { Korelasi }=\frac{\sum_{i} \sum_{j}(i, j) \cdot p(i, j)-\mu_{x} \mu_{y}}{\sigma_{x} \sigma_{y}}
$$

Dengan:

$\mu_{x}$ : rata-rata dari $p(i) \quad \sigma_{\mathrm{x}}$ : simpangan balik dari $p(i)$

$\mu_{y}$ : rata-rata dari $p(j) \quad \sigma_{\mathrm{y}}$ : simpangan balik dari $p(j)$

$p(i, j)$ : nilai pada baris i dan kolom $\mathrm{j}$ pada matriks kookurensi

\section{Entropi}

Entropi menunjukkan ukuran ketidakteraturan bentuk. Harga entropi besar untuk citra dengan transisi derajat keabuan merata dan bernilai kecil jika struktur citra tidak teratur (bervariasi).

$$
\text { Entropi }=-\sum_{i} \sum_{j} p(i, j) \cdot \log p(i, j)
$$

Dengan $p(i, j)$ menyatakan nilai pada baris i dan kolom j pada matriks kookurensi.

\section{Homogenitas}

Homogenitas yaitu untuk mengukur kehomogenan variasi intensitas dalam citra. Nilai homogenitas membesar bila variasi intensitas dalam citra mengecil dan sebaliknya.

$$
\text { Homogenitas }=\sum_{i} \sum_{j} \frac{p(i, j)}{1+|i-j|}
$$


Pengembangan Rekayasa dan Teknologi, Vol 16, No. 1, Juni 2020, pp 34-44

p-ISSN: $1410-9840$ \& e-ISSN: $2580-8850$

http://journals.usm.ac.id/index.php/jprt/index

Dengan $p(i, j)$ menyatakan nilai pada baris i dan kolom j pada matriks kookurensi.

\section{PERANCANGAN SISTEM}

Bab ini membahas alat dan bahan penelitian, tahapan proses pengolahan citra, dan perancangan antarmuka aplikasi untuk identifikasi jenis kurma. Penelitian ini menggunakan 90 citra data latih dan 30 citra data uji. Data latih terdiri atas masing-masing 30 citra kurma Ajwa, kurma Sukari, dan kurma Deglet Nour. Data uji terdiri atas masing-masing 10 citra kurma Ajwa, kurma Sukari, dan kurma Deglet Nour. Semua citra yang digunakan berukuran $3000 \mathrm{x} 4000 \mathrm{px}$ dengan ukuran file sebesar 1,3MB -1,5MB.

\section{a. Alat dan Bahan Penelitian}

Alat dan bahan yang akan digunakan dalam penelitian ini adalah sebagai berikut.
1. Komputer dengan prosesor Ryzen 51600 3,6Ghz dan RAM 8GB.

2. Sistem Operasi Windows 10 Pro.

3. Xiaomi Redmi Note 5 dengan kamera belakang 12 megapiksel.

4. Perangkat lunak pengembang aplikasi yaitu Android Studio.

5. Kotak cahaya.

6. Kurma Ajwa.

7. Kurma Sukari.

8. Kurma Deglet Nour.

\section{b. Algoritma Perancangan Aplikasi}

Bagan alir merupakan bagan yang mewakili algoritma dan proses aplikasi identifikasi jenis kurma yang sedang berjalan. Proses jalannya aplikasi secara runtun dapat digambarkan menjadi diagram alir program seperti pada gambar 3.1. 
Pengembangan Rekayasa dan Teknologi, Vol 16, No. 1, Juni 2020, pp 34-44

p-ISSN: $1410-9840$ \& e-ISSN: $2580-8850$

http://journals.usm.ac.id/index.php/jprt/index



Gambar 3.1 Bagan alir proses identifikasi citra

Pada bagan alir di atas menunjukkan proses identifikasi citra. Tahapan pertama adalah pengambilan citra. Pengambilan citra dapat dilakukan dengan dua cara yaitu menggunakan kamera atau mengambil citra pada galeri. Tahap selanjutnya citra akan diubah menjadi citra dengan aras keabuan. Selanjutnya pembuatan mask dengan menggunakan pengambangan Otsu dan Binary Inv. Hasil dari pengambangan dilakukan proses morfologi closing untuk menghilangkan derau yang berada di dalam area mask. Kemudian melakukan proses segmentasi dengan menggabungkan citra asli dengan mask yang telah dibuat. Hasil dari segmentasi kemudian di ekstraksi ciri statistik orde kedua dengan metode
GLCM untuk menentukan jenis kurma yang di identifikasi.

\section{c. Perancangan Antarmuka Aplikasi}

Perancangan antarmuka atau tampilan sangat diperlukan untuk memberikan suatu gambaran serta penjelasan dari setiap proses berjalannya aplikasi dari awal hingga selesai. Perancangan ini memuat isi dari setiap halaman yang ditampilkan seperti kegunaan tombol, teks dan gambar. Fungsi dari perancangan ini adalah untuk memberikan antarmuka aplikasi yang lebih menarik dan terstruktur agar lebih mudah dipahami saat dioperasikan. 
Pengembangan Rekayasa dan Teknologi, Vol 16, No. 1, Juni 2020, pp 34-44

p-ISSN: $1410-9840$ \& e-ISSN: 2580-8850

http://journals.usm.ac.id/index.php/jprt/index

\section{Halaman Utama}

Halaman utama aplikasi merupakan halaman yang berisi menu-menu utama dari aplikasi. Gambar 3.2 menunjukkan rancangan antarmuka halaman utama aplikasi.

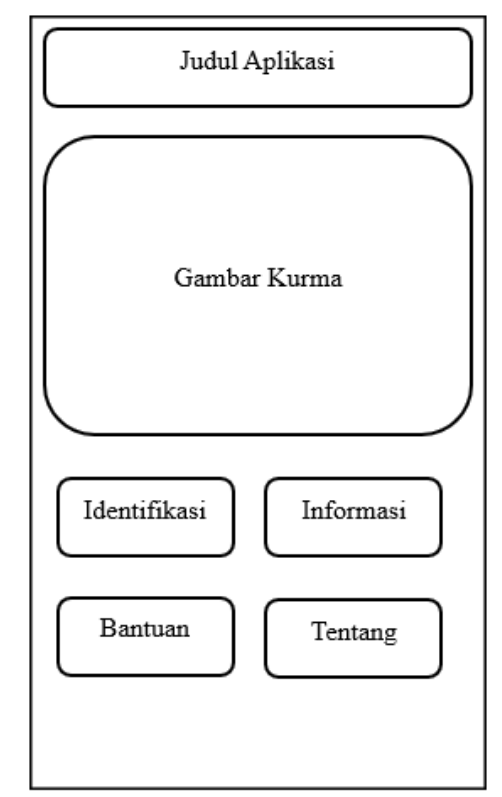

Gambar 3.2 Halaman utama aplikasi

Pada halaman utama terdapat 4 menu utama yaitu Identifikasi, Informasi, Bantuan, dan Tentang. Menu identifikasi digunakan untuk mengarahkan pengguna menuju ke halaman pilih citra untuk melakukan identifikasi. Menu Informasi digunakan untuk mengarahkan pengguna menuju ke halaman informasi yang berisi informasi umum tiap jenis kurma. Menu Bantuan digunakan untuk mengarahkan pengguna menuju ke halaman bantuan yang berisi panduan cara menggunakan aplikasi dengan benar. Menu Tentang digunakan untuk mengarahkan pengguna menuju ke halaman tentang yang berisi informasi mengenai fungsi dari aplikasi dan pengembang aplikasi.

\section{Halaman Pilih Citra}

Halaman pilih citra merupakan halaman yang digunakan untuk memilih citra kurma melalui kamera ponsel pintar secara langsung atau melalui galeri yang akan digunakan untuk identifikasi. Gambar 3.3 menunjukkan rancangan antarmuka halaman pilih citra.

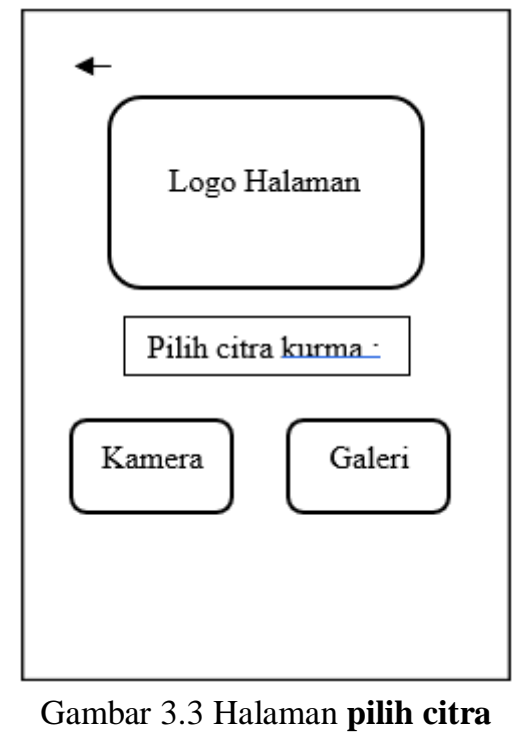

\section{Halaman Pratinjau Citra}

Halaman pratinjau citra merupakan halaman yang digunakan untuk menampilkan citra kurma yang telah dipilih. Gambar 3.5 menunjukkan rancangan antarmuka halaman pratinjau citra.

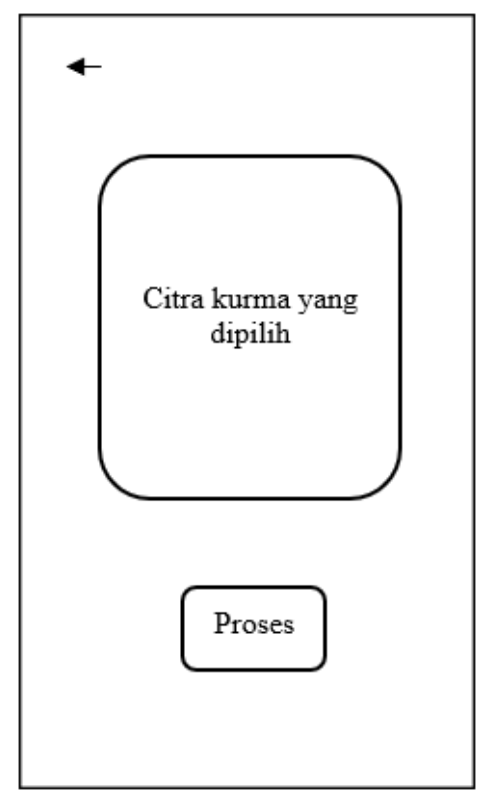

Gambar 3.5 Halaman pratinjau citra

\section{Halaman Hasil Identifikasi}

Halaman hasil identifikasi merupakan halaman yang digunakan untuk menampilkan citra asli, citra setelah melalui pemrosesan, dan analisis hasil identifikasi jenis kurma. Gambar 3.6 menunjukkan rancangan antarmuka halaman hasil identifikasi. 
Pengembangan Rekayasa dan Teknologi, Vol 16, No. 1, Juni 2020, pp 34-44

p-ISSN: $1410-9840$ \& e-ISSN: $2580-8850$

http://journals.usm.ac.id/index.php/jprt/index

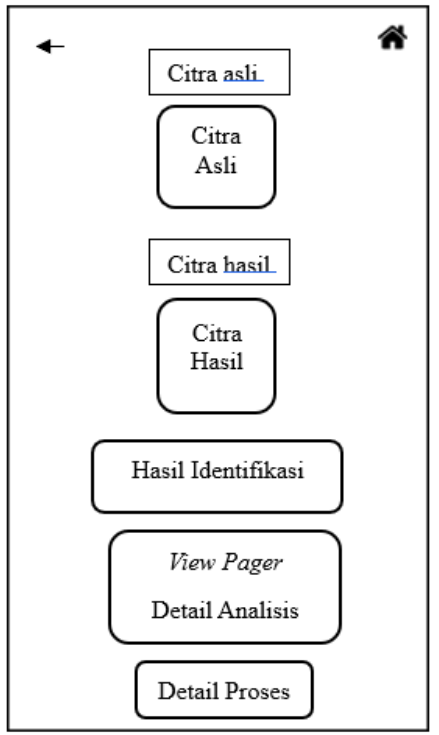

Gambar 3.6 Halaman hasil identifikasi

\section{Halaman Detail Proses}

Halaman detail proses merupakan halaman yang digunakan untuk menampilkan hasil citra dari tiap tahapan proses pengolahan citra. Gambar 3.7 menunjukkan rancangan antarmuka halaman detail proses.

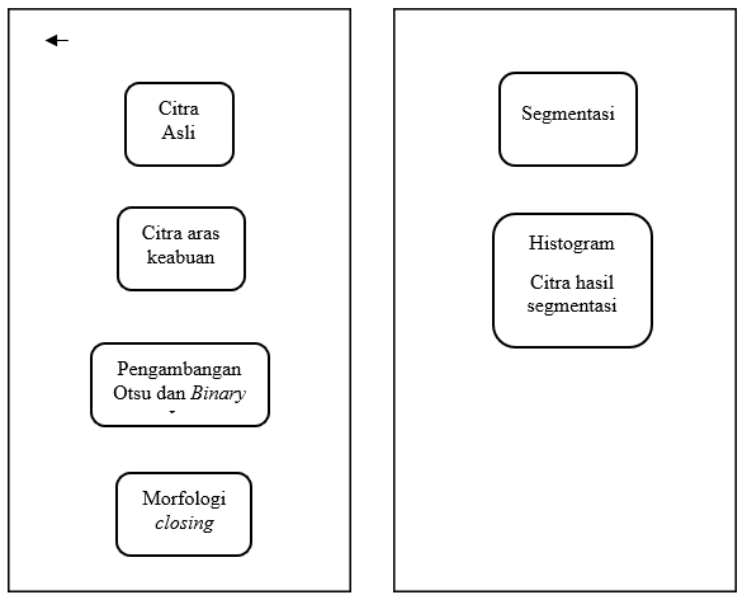

Gambar 3.7 Halaman detail proses

\section{IMPLEMENTASI DAN PENGUJIAN}

\section{a. Implementasi Antarmuka Aplikasi}

Tahap implementasi ini merupakan hasil penerjemahan perancangan aplikasi ke dalam senarai program sehingga menghasilkan antarmuka yang diharapkan.

\section{Halaman Utama}

Halaman utama aplikasi merupakan halaman yang berisi menu-menu utama dari aplikasi. Gambar 4.1 menunjukkan tampilan halaman utama aplikasi.

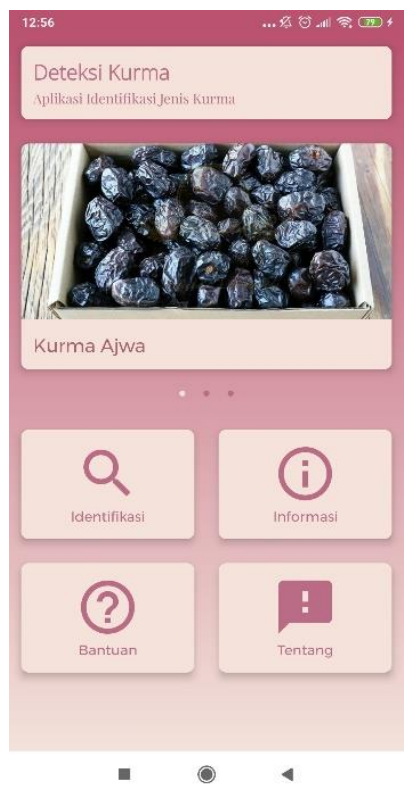

Gambar 4.1 Tampilan halaman utama

\section{Halaman Pilih Citra}

Halaman pilih citra merupakan halaman yang digunakan untuk memilih citra kurma melalui kamera ponsel pintar secara langsung atau melalui galeri yang akan digunakan untuk identifikasi. Gambar 4.2 menunjukkan tampilan halaman pilih citra.

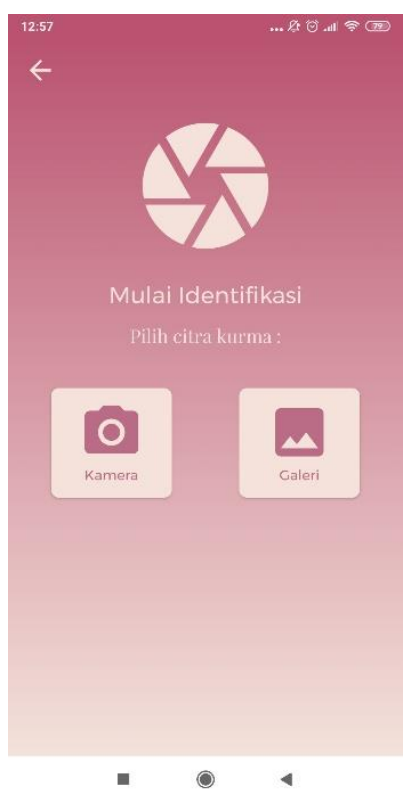

Gambar 4.2 Tampilan halaman pilih citra 
Pengembangan Rekayasa dan Teknologi, Vol 16, No. 1, Juni 2020, pp 34-44

p-ISSN: $1410-9840$ \& e-ISSN: 2580-8850

http://journals.usm.ac.id/index.php/jprt/index

\section{Halaman Pratinjau Citra}

Halaman pratinjau citra merupakan halaman yang digunakan untuk menampilkan citra kurma yang telah dipilih. Gambar 4.3 menunjukkan tampilan halaman pratinjau citra.

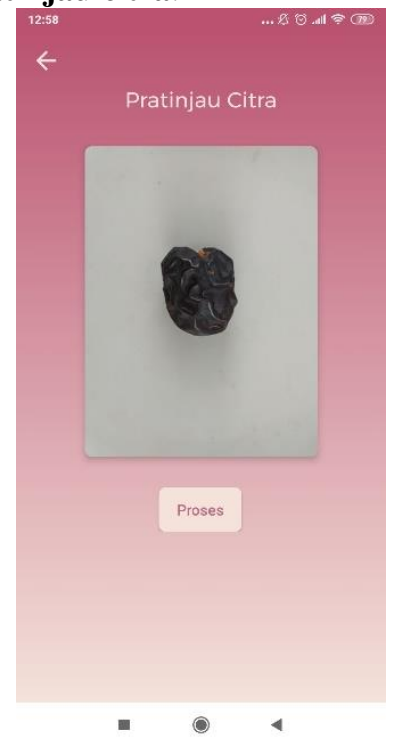

Gambar 4.3 Tampilan halaman pratinjau citra

\section{Halaman Hasil Identifikasi}

Halaman hasil identifikasi merupakan halaman yang digunakan untuk menampilkan citra asli, citra setelah melalui proses pengolahan citra, dan analisis hasil identifikasi jenis kurma. Gambar 4.4 menunjukkan tampilan halaman hasil identifikasi.
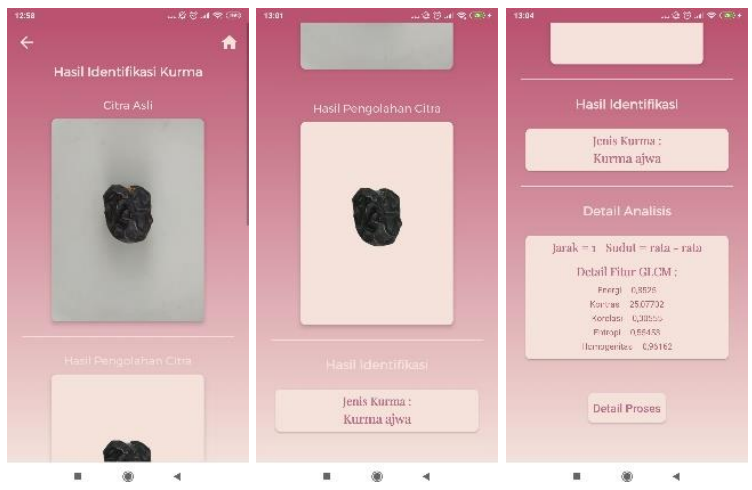

Gambar 4.4 Tampilan halaman hasil identifikasi

\section{Halaman Detail Proses}

Halaman detail proses merupakan halaman yang digunakan untuk menampilkan hasil citra dari tiap tahapan proses pengolahan citra.

\section{b. Pengujian Aplikasi}

Pengujian aplikasi identifikasi jenis buah kurma dilakukan dengan menggunakan metode kotak-hitam (black box). Tahapan pengujian ini berisi rangkaian pengujian tombol dan fungsi yang terdapat dalam aplikasi. Pengujian ini dilakukan yang bertujuan untuk memeriksa semua tombol dan fungsi dari aplikasi sudah bekerja sesuai dengan kebutuhan aplikasi. Tabel 4.1 menunjukkan pengujian fungsi pada aplikasi.

Tabel 4.1 Daftar pengujian kotak-hitam pada aplikasi

\begin{tabular}{|c|c|c|c|c|}
\hline No & $\begin{array}{c}\text { Nama } \\
\text { Pengujian }\end{array}$ & $\begin{array}{c}\text { Bentuk } \\
\text { Pengujian }\end{array}$ & $\begin{array}{c}\text { Hasil yang } \\
\text { Diharapkan }\end{array}$ & $\begin{array}{c}\text { Hasil } \\
\text { Pengujian }\end{array}$ \\
\hline 1. & $\begin{array}{l}\text { Pengujian } \\
\text { menjalankan } \\
\text { aplikasi }\end{array}$ & $\begin{array}{c}\text { Menekan icon } \\
\text { launcher aplikasi }\end{array}$ & $\begin{array}{c}\text { Aplikasi berhasil } \\
\text { dijalankan dan } \\
\text { masuk ke tampilan } \\
\text { awal }\end{array}$ & Berhasil \\
\hline 2. & $\begin{array}{l}\text { Pengujian } \\
\text { tombol } \\
\text { Identifikasi }\end{array}$ & $\begin{array}{l}\text { Pada halaman } \\
\text { utama aplikasi, } \\
\text { menekan tombol } \\
\text { Identifikasi }\end{array}$ & $\begin{array}{l}\text { Masuk ke halaman } \\
\text { pilih citra }\end{array}$ & Berhasil \\
\hline 3. & $\begin{array}{c}\text { Pengujian } \\
\text { mengambil citra } \\
\text { menggunakan } \\
\text { kamera } \\
\end{array}$ & $\begin{array}{l}\text { Pada halaman } \\
\text { pilih citra, } \\
\text { menekan tombol } \\
\text { Kamera } \\
\end{array}$ & $\begin{array}{l}\text { Masuk ke dalam } \\
\text { kamera dan dapat } \\
\text { mengambil citra }\end{array}$ & Berhasil \\
\hline 4. & $\begin{array}{l}\text { Pengujian } \\
\text { memilih citra } \\
\text { pada galeri }\end{array}$ & $\begin{array}{l}\text { Pada halaman } \\
\text { pilih citra, } \\
\text { menekan tombol } \\
\text { Galeri } \\
\end{array}$ & $\begin{array}{l}\text { Masuk ke dalam } \\
\text { galeri dan dapat } \\
\text { memilih citra }\end{array}$ & Berhasil \\
\hline 5. & $\begin{array}{l}\text { Pengujian } \\
\text { tombol Proses }\end{array}$ & $\begin{array}{l}\text { Pada halaman } \\
\text { pratinjau citra, } \\
\text { menekan tombol } \\
\text { Proses }\end{array}$ & $\begin{array}{c}\text { Masuk ke halaman } \\
\text { hasil identifikasi } \\
\text { dan menampilkan } \\
\text { citra asli, citra } \\
\text { hasil, dan hasil } \\
\text { analisis }\end{array}$ & Berhasil \\
\hline 6. & $\begin{array}{l}\text { Pengujian } \\
\text { tombol Detail } \\
\text { Proses }\end{array}$ & $\begin{array}{c}\text { Pada halaman } \\
\text { hasil identifikasi, } \\
\text { menekan tombol } \\
\text { Detail Process }\end{array}$ & $\begin{array}{c}\text { Masuk ke halaman } \\
\text { detail proses dan } \\
\text { menampilkan citra } \\
\text { tiap proses } \\
\text { pengolahan citra }\end{array}$ & Berhasil \\
\hline 7. & $\begin{array}{l}\text { Pengujian } \\
\text { tombol } \\
\text { Informasi }\end{array}$ & $\begin{array}{l}\text { Pada halaman } \\
\text { utama aplikasi, } \\
\text { menekan tombol } \\
\text { Informasi }\end{array}$ & $\begin{array}{c}\text { Masuk ke halaman } \\
\text { informasi dan } \\
\text { menampilkan } \\
\text { informasi jenis } \\
\text { kurma }\end{array}$ & Berhasil \\
\hline 8. & $\begin{array}{c}\text { Pengujian } \\
\text { tombol Bantuan }\end{array}$ & $\begin{array}{c}\text { Pada halaman } \\
\text { utama aplikasi, } \\
\text { menekan tombol } \\
\text { Bantuan }\end{array}$ & $\begin{array}{c}\text { Masuk ke halaman } \\
\text { bantuan dan } \\
\text { menampilkan } \\
\text { panduan cara } \\
\text { menggunakan } \\
\text { aplikasi } \\
\end{array}$ & Berhasil \\
\hline 9. & $\begin{array}{c}\text { Pengujian } \\
\text { tombol Tentang }\end{array}$ & $\begin{array}{l}\text { Pada halaman } \\
\text { utama aplikasi, } \\
\text { menekan tombol } \\
\text { Tentang }\end{array}$ & $\begin{array}{l}\text { Masuk ke halaman } \\
\text { tentang dan } \\
\text { menampilkan } \\
\text { informasi fungsi } \\
\text { dari aplikasi dan } \\
\text { pengembang } \\
\text { aplikasi }\end{array}$ & Berhasil \\
\hline 10. & $\begin{array}{l}\text { Pengujian keluar } \\
\text { dari aplikasi }\end{array}$ & $\begin{array}{l}\text { Pada halaman } \\
\text { utama aplikasi, } \\
\text { menekan tombol } \\
\text { kembali dua kali }\end{array}$ & Keluar dari aplikasi & Berhasil \\
\hline
\end{tabular}

Tabel 4.1 menunjukkan hasil pengujian kotakhitam terhadap aplikasi identifikasi jenis kurma telah berhasil semua. Seluruh tombol dan fungsi dari aplikasi berjalan dengan lancar sesuai dengan spesifikasi kebutuhan aplikasi.

\section{c. Hasil Identifikasi}

Hasil identifikasi citra diperoleh dari perhitungan GLCM dengan parameter energi, kontras, korelasi, entropi, dan homogenitas. Nilai tiap parameter diambil dari rata-rata semua sudut $\left(0^{\circ}, 45^{\circ}, 90^{\circ}\right.$, dan $\left.135^{\circ}\right)$. 
Pengembangan Rekayasa dan Teknologi, Vol 16, No. 1, Juni 2020, pp 34-44

p-ISSN: $1410-9840$ \& e-ISSN: $2580-8850$

http://journals.usm.ac.id/index.php/jprt/index

Proses identifikasi yang dilakukan dengan cara membandingkan rentang nilai rata-rata tiap parameter jenis kurma satu dengan yang lainnya.

Dari 90 citra data latih sudah diketahui kategori kelompoknya yaitu 30 data citra kurma Ajwa, 30 data citra kurma Sukari, dan 30 data data citra kurma Deglet Nour. Dari 90 citra data latih didapatkan rentang nilai tiap parameter GLCM seperti ditunjukkan pada Tabel 4.2.

Tabel 4.2 Daftar rentang nilai parameter GLCM semua jenis kurma

\begin{tabular}{|c|c|c|c|c|c|}
\hline \multirow{2}{*}{ Jenis } & \multicolumn{5}{|c|}{ Rentang Nilai } \\
\cline { 2 - 6 } Kurma & Energi & Kontras & Korelasi & Entropi & Homogenitas \\
\hline Kurma & $0,842 \leq$ & $17,282 \leq$ & $0,005 \leq$ & $0,46 \leq$ & $0,956 \leq$ \\
Ajwa & Energi & Kontras & Korelasi & Entropi & Homogenitas \\
& $\leq 0,879$ & $\leq 32,193$ & $\leq 0,008$ & $\leq 0,593$ & $\leq 0,971$ \\
\hline & $0,77 \leq$ & $41,329 \leq$ & $0,001 \leq$ & $0,591 \leq$ & $0,929 \leq$ \\
Kurma & Energi & Kontras & Korelasi & Entropi & Homogenitas \\
Sukari & $\leq 0,85$ & $\leq 71,241$ & $\leq 0,002$ & $\leq 0,948$ & $\leq 0,965$ \\
\hline Kurma & $0,772 \leq$ & $22,07 \leq$ & $0,002 \leq$ & $0,528 \leq$ & $0,944 \leq$ \\
Deglet & Energi & Kontras & Korelasi & Entropi & Homogenitas \\
Nour & $\leq 0,868$ & $\leq 54,651$ & $\leq 0,006$ & $\leq 0,849$ & $\leq 0,973$ \\
\hline
\end{tabular}

Tabel 4.2 menunjukkan daftar rentang nilai parameter GLCM tiap jenis kurma yang digunakan sebagai acuan untuk identifikasi jenis kurma.

Citra kurma yang memiliki nilai parameter sesuai dengan rentang nilai jenis kurma maka citra tersebut akan dikenali sebagai jenis kurma yang sesuai dengan acuan rentang nilai. Citra yang memiliki nilai parameter selain dari nilai acuan maka citra tersebut tidak dapat terdeteksi.

Berdasarkan 5 rentang nilai parameter GLCM terdapat 2 parameter yang memiliki rentang nilai yang berbeda tiap jenis kurma yaitu korelasi dan entropi. Dari parameter entropi dan korelasi dapat dibuat sebuah grafik persebaran jenis kurma. Data grafik yang digunakan adalah 30 citra data uji hasil identifikasi yang terdiri dari 10 citra kurma Ajwa, 10 citra kurma Sukari, dan 10 citra kurma Deglet Nour. Gambar 4.6 menunjukkan grafik penyebaran hasil identifikasi tiap jenis kurma.

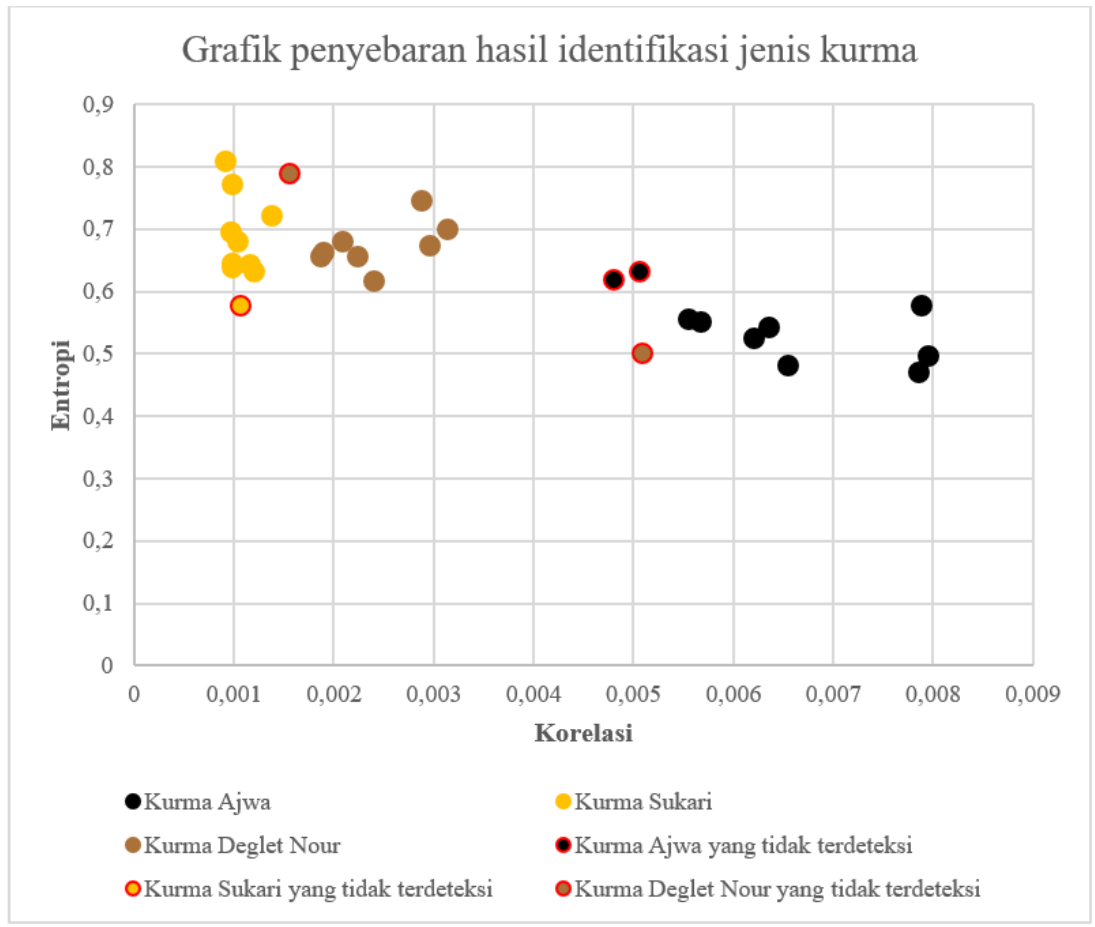

Gambar 4.6 Grafik hasil identifikasi jenis kurma

Gambar 4.6 menunjukkan grafik penyebaran hasil identifikasi jenis kurma yang memiliki sumbu $\mathrm{x}$ sebagai nilai korelasi dan sumbu y sebagai nilai entropi. Terdapat 8 titik berwarna hitam yang menunjukkan citra jenis kurma Ajwa dengan rentang nilai korelasi sebesar 0,005 sampai dengan 0,008 dan rentang nilai entropi sebesar 0,46 sampai dengan 0,593 . Terdapat 9 titik berwarna kuning yang menunjukkan citra jenis kurma Sukari dengan rentang nilai korelasi sebesar 0,001 sampai dengan 0,002 dan rentang nilai entropi 0,591 sampai dengan 0,948 . Terdapat 8 titik berwarna cokelat yang menunjukkan citra jenis kurma Deglet Nour dengan rentang nilai korelasi sebesar 0,002 sampai dengan 0,006 dan rentang nilai entropi 0,528 sampai dengan 0,849 . Terdapat 2 titik berwarna hitam dengan tepi berwarna merah yang menunjukkan citra jenis kurma Ajwa yang terdeteksi kurma Deglet Nour. Terdapat 1 titik 
Pengembangan Rekayasa dan Teknologi, Vol 16, No. 1, Juni 2020, pp 34-44

p-ISSN: $1410-9840$ \& e-ISSN: $2580-8850$

http://journals.usm.ac.id/index.php/jprt/index

berwarna kuning dengan tepi berwarna merah yang menunjukkan citra jenis kurma Sukari yang tidak terdeteksi. Terdapat 2 titik berwarna cokelat dengan tepi berwarna merah yang menunjukkan citra kurma jenis Deglet Nour yang tidak terdeteksi.

\section{d. Tingkat Akurasi Aplikasi}

Tingkat akurasi aplikasi digunakan untuk menghitung persentase seberapa besar aplikasi membaca data dengan benar. Berdasarkan hasil identifikasi data uji terdapat total 5 kesalahan identifikasi yaitu citra nomor 5 dan 8 kurma ajwa, nomor 5 kurma Sukari, dan nomor 5 dan 6 kurma Deglet Nour dari 30 citra kurma yang diuji. Dari hasil tersebut tingkat akurasi pada aplikasi identifikasi jenis kurma adalah $83,33 \%$ yang didapatkan dari:

$$
\text { Akurasi }=100 \%-\frac{5}{30} \times 100 \%=83,33 \%
$$

\section{Kesimpulan}

a. Kesimpulan

Berdasarkan penelitian yang telah dilakukan diperoleh beberapa kesimpulan sebagai berikut.

1. Proses merancang aplikasi untuk identifikasi ketiga jenis kurma dilakukan dengan pengubahan citra RGB menjadi citra aras keabuan, segmentasi pengambangan dengan algoritma Otsu dan Binary Inv, morfologi closing, segmentasi Binary, ekstraksi ciri statistik orde kedua dengan GLCM, dan identifikasi dengan membandingkan nilai parameter GLCM.

2. Untuk mendapatkan hasil yang optimal, proses pengambilan citra dilakukan menggunakan kotak cahaya (light box) dengan penerangan lampu yang diatur menggunakan dua lampu jenis LED berwarna putih yang memiliki daya masing masing sebesar 6 watt.

3. Dengan menggunakan 90 citra data latih dan 30 citra data uji, diperoleh tingkat akurasi keberhasilan sebesar 83,33\% pada identifikasi 3 (tiga) jenis kurma: Ajwa, Sukari, dan Deglet Nour.

4. Aplikasi berhasil digunakan untuk mendeteksi jenis kurma Ajwa, kurma Sukari, dan kurma Deglet Nour menggunakan nilai rata-rata semua sudut matriks kookurensi $\left(0^{\circ}, 45^{\circ}, 90^{\circ}\right.$, dan $\left.135^{\circ}\right)$ dari setiap parameter (energi, kontras, korelasi, entropi, dan homogenitas) pada metode GLCM.

5. Berdasarkan 5 parameter GLCM terdapat 2 parameter yang memiliki rentang nilai yang berbeda tiap jenis kurma yaitu entropi dan korelasi. Dari kedua parameter tersebut dapat dibuat sebuah grafik penyebaran hasil identifikasi jenis kurma untuk klasifikasi jenis kurma.

\section{b. Saran}

Berdasarkan kesimpulan dari penelitian yang telah dilakukan, saran yang dapat diberikan untuk penelitian selanjutnya adalah sebagai berikut.

1. Perlu dilakukan penelitian lanjutan menggunakan metode lain, misalnya KNN atau jenis JST yang lain, untuk selanjutnya dibandingkan dengan penelitian ini agar dapat ditentukan metode mana yang hasilnya optimal untuk mengidentifikasi buah kurma.

2. Perlu dilakukan penelitian lanjutan yang memungkinkan proses deteksi dengan pengambilan citra kurma yang tidak bergantung pada kotak cahaya, namun dengan tingkat keberhasilan yang lebih baik.

\section{DAFTAR PUSTAKA}

[1] Novianto, H., Kurma kian deras masuk ke Indonesia, mayoritas dari Mesir, Beritagar. 2019.

[2] Sumandra, S., Kurma dalam Perspektif Qur'an, Hadits, dan Sains. Yogyakarta, Js UGM. 2019.

[3] A. Manickavasagan, K. Ganeshmoorthy, M. R. Claereboudt, R. Al-Yahyai and L. Khriji., Nondestructive measurement of total soluble solid (TSS) content of dates using near infrared (NIR) imaging, Emir. J. Food Agric, 2014.

[4] Sonata, V., Klasifikasi Jenis Buah Kurma Menggunakan Teknik Pengolahan Citra Digital Dengan Metode Jaringan Syaraf Tiruan, Skripsi S-1, Universitas Gajah Mada, Yogyakarta, 2015.

[5] Ayman A.A. Ibrahim, Ayman H. Amer Eissa, Abdul Rahman O. Alghannam., Image Processing System For Automated Classification Date Fruit, International Journal of Advanced Research, ISSN 2320-5407, 2014.

[6] M. A. Al-Farsi, C. Y. Lee., Nutritional and Functional Properties of Dates: A Review, Crit. Rev. Food Sci. Nutr., vol. 48, no. 10, pp. 877887, 2008.

[7] Putri, Z., Cara Mengetahui Perbedaan Kurma Ajwa Asli Dan Palsu, Kurma Sehat, 2015.

[8] Rio, M., Serba Serbi Kurma Sukari, Grosir Kurma, 2017.

[9] D. Putra, Pengolahan Citra Digital. Penerbit Andi. Yogyakarta. 2010.

[10] Sutoyo, T., E. Mulyanto, V. Suhartono, O.D. Nurhayati, dan Wijanarto, Teori Pengolahan Citra Digital, Penerbit Andi, Yogyakarta, 2009.

[11] Munir, R. Aplikasi Image Thresholding Untuk Segmentasi Objek, Seminar Nasional Aplikasi 
Pengembangan Rekayasa dan Teknologi, Vol 16, No. 1, Juni 2020, pp 34-44

p-ISSN: $1410-9840$ \& e-ISSN: $2580-8850$

http://journals.usm.ac.id/index.php/jprt/index

Teknologi Informasi - ISSN: 1907-5022, Yogyakarta, 2006.

[12] Hendry, J., Image Thresholding Using Otsu, EE \& IT of UGM, Yogyakarta 2012.

[13] Listia, R., dan A. Harjoko, Klasifikasi Massa pada Citra Mammogram Berdasarkan Gray Level Cooccurence Matrix (GLCM). Jurnal UGM, Yogyakarta, 2014.

[14] Aris., Penerapan Algoritma Grey Level CoOccurence Matrix (GLCM) Dengan Metode KNearest Neighbour Untuk Klasifikasi Beras Berdasarkan Tekstur, Skripsi S-1, UNIKOM, Bandung, 2015.

\section{BIOGRAFI PENULIS}

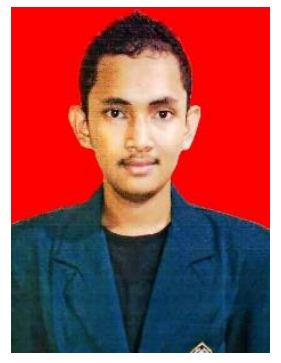

Penulis bernama Mochamad Fandi, anak tunggal, lahir di Semarang, Provinsi Jawa Tengah pada tanggal 10 Juli 1997. Riwayat pendidikan penulis dimulai dari bersekolah di SD HJ. Isriati Baiturahman 1 Semarang pada tahun 2003 dan tamat pada tahun 2009, dilanjutkan dengan menempuh Pendidikan di SMP N 6 Semarang pada tahun 2009 hingga tahun 2012, dilanjutkan ke jenjang selanjutnya di SMA N 1 Semarang pada tahun 2012 hingga tahun 2015. Kini penulis sedang menempuh Pendidikan Strata-1 Departemen Teknik Komputer di Universitas Diponegoro, Semarang. 